Storvoll, R. (2018). Unge framtidsstemmer i Nord.

Scandinavian Journal og Vocations in development

DOI: https://doi.org/10.7577/sjvd.2617

Fagfellevurdert artikkel (Peer reviewed article)

\title{
Unge framtidsstemmer i nord
}

Forfatter:

Ragnvald Storvoll

Norges arktiske universitet, Studiesenteret Finnsnes

ragnvald.storvoll@dyroy.kommune.no

Nøkkelord: Framtidsperspektiver - Unge - Glokale borgere - Næringsutvikling Brain drain - Ungdomsmedvirkning - Læring - Stedsutvikling - Globalisering Flerstedstilknytning - Stedstilknytning - Stedspolygami - Trainee - Framtidstro 


\section{Introduksjon}

I Nord-Norge er det lyse framtidsperspektiver på flere felt. Det er store naturressurser, arbeidsplasser skapes, ikke minst innenfor sjømat og reiseliv, og arbeidsledigheten er lav. Imidlertid kaster demografien et dystrere lys over framtida; antall eldre øker, ungdomskullene blir mindre og fare for at velutdannet arbeidskraft forlater landsdelen er stor, såkalt braindrain. Det er de unge som er avgjørende for framtida. Deres valg av utdanning og bosted vil påvirke utviklingen også i vår landsdel.

Denne artikkelen handler om hvordan ungdom i Troms ser på framtiden i nord. På den ene siden formidles en statistisk beskrivelse av framtidsperspektiver av Nord-Norge fra SSB, media og også forskere, som kan oppleves som en negativ trussel. I første del av artikkelen beskrives et demografisk framtidsbilde for landsdelen. Dette kan bli en negativ prediksjon, nærmest en selvoppfyllende profeti. På den andre siden vokser ungdom opp i en landsdel med svært positive framtidsmuligheter; turiststrømmen øker, Nord-Norge opplever en raskere økonomisk vekst enn resten av landet, og mange nye arbeidsplasser ser dagens lys. «Mulighetens landsdel» brukes av mange. I dette skjæringspunktet har jeg har utfordret ungdom, primært i Midt-Troms, om deres forståelse og syn på framtida.

Det overordnede forskningsspørsmålet i artikkelen er som følger: Hva sier ungdommer fra Midt-Troms om sin framtid? I tillegg stilles to underordnede forskningsspørsmål: Hvilke næringer ser disse ungdommene som de viktigste for regionens vekst og utvikling? Hvilke faktorer mener de unge bidrar og hindrer vekst?

Artikkelen er en av flere som inngår i et doktorgradsarbeid der kunnskap om stedsutvikling, primært i nordområdene, er sentralt. Ny teknologi, bredbånd og annen organisering av arbeidslivet, gjør det mulig å løse en rekke arbeidsoppgaver stedsuavhengig. For små kommuner med utfordrende arbeidsmarked, er tilrettelegging for stedsuavhengig arbeid en mulig strategi for økt tilflytting og mer variert arbeidsliv. Ungdom er en avgjørende ressurs å samhandle med for å gjøre gode grep for framtida i nord.

\section{Demografisk bakgrunn og noen teoretiske perspektiver}

Forskning viser at det er en sterk sentraliseringstrend i Norge og globalt ved at en stadig større andel av befolkningen bor i byer og tettbebygde strøk (United Nations (UN), 2006). Selv om Nord-Norge har en forventet vekst, er den lav sammenlignet med befolkningsveksten i andre 
landsdeler. Prognosene til Statistisk sentralbyrå (SSB) viser at Oslo og Akershus vil ha den største veksten på 30 prosent (Leknes, Tønnessen \& Syse, 2016).

I 2012 utgjorde nordlendinger 9,4 prosent av den norske befolkningen, mens den ifølge prognosene til SSB vil utgjøre 8,1 prosent i 2040. Nord-Norges andel av Norges befolkning var på sitt historisk laveste nivå i 1769 med 8,2 prosent (SSB, 2012). En stor demografisk utfordring i Midt-Troms er at antall eldre vil øke raskere enn forventet ung befolkningstilvekst. I følge SSB vil denne regionen øke med 3000 fram til 2040. Nesten all økning vil komme i aldergruppen over 67 år. I 2014 var det 1653 ungdommer i alderen 16-19 år i Midt-Troms, mens SSB i sin framskriving forteller at antallet i 2030 vil være nede i 1490 , altså en nedgang på ca. ti prosent. Bildet av demografiutviklingen er relativt likt i hele nord, med få unntak knyttet til noen byer og tettsteder. Flere analyser, blant annet for Sør-Troms, (Ringholm, Mikkelsen, Alnes, Hauge, Lie, Nilsen \& Grønvold-Solbu, 2015), bekrefter mine funn og forteller om den samme tendensen. Dette i seg selv er urovekkende, noe også ungdommen gir uttrykk for. Spiralen forsterkes i ei negativ retning; når de unge flytter, fører det til at barnetallene går ned og befolkningen minker.

Det er gjennomført forskning som ikke bare framskriver prognoser, men som også har undersøkt hvor det blir av de unge voksne fra nord. Blir de igjen på hjemplassen eller flytter de sørover? Forskerne Leknes, S., M. Tønnessen og A. Syse (2016) har sett nærmere på bosettingsmønsteret til alle barn som ble født i Nord-Norge mellom 1986-1991. Kartlegging av denne attraktive gruppen, som i dag er 25-30 år, har sammenlignet hvor de er født og hvor de unge i dag har sin folkeregistrerte adresse. I denne femårsperioden er det født 39.223 personer i Nord-Norge i landsdelens 85 kommuner. Kartleggingen viser blant annet at det $\mathrm{i}$ snitt var 4 av 10 som ble værende på hjemplassen. 3 av 10 flyttet til Sør-Norge, 2 av 10 flyttet fra hjemplassen, men bor fortsatt i nord. Resten er utvandret eller døde. Resultatet forklarer, ikke uventet, en sentraliseringstrend, som både reflekteres og bekreftes i Statistisk sentralbyrås prognoser for befolkningsutviklingen i Norge. I arbeidet til Leknes m. fl. (Leknes, Tønnesen \& Syse, 2016), ser en at det er flere 30-åringer enn 25-åringer som har flyttet ut. Selv om utvandringen til Sør-Norge synker gradvis gjennom femårsperioden i denne forskningen, er det ikke grunnlag for å si at dette er en endring av mer permanent karakter. Det er ikke gjort nyere forskning som viser hvor unge fra Midt-Troms flytter. 
$\AA$ forstå nyere stedteori og -tilknytning, betrakter jeg som sentralt. Stedsteorier utfordres for det første av at steder, og hva folk oppfatter som steder, det endres. For det andre utfordres de av politiske prosesser. Demografiske endringer, som det vises til i denne artikkelen, kan være et eksempel. Og for det tredje inspirerer nye teoretiske trender til nye spørsmål. Det er mange trekk i samfunnsutviklingen som gjør steder viktige og gjør at nye perspektiver på og teorier om sted utvikles. Økt mobilitet i verden, mer oppmerksomhet på flyt av mennesker, produkter og idéer og mer intense globaliseringsprosesser, har i mange år vært brukt for å studere samfunnsmessige fenomen på nye måter. På 90-tallet var det en større diskusjon om steder var i ferd med å miste sin betydning for menneskers hverdagsliv. Giddens (1991) og Castells (1996) stod for et slikt syn, mens andre som Castree (2003) viste til at steder blir viktige på helt andre måter enn før. I dag er det et rådende syn at «geography matters!» (Massey, 2005) Dette bekreftes både av hverdagsobservasjoner og mer systematiske empiriske studier (Perkins \& Thorns, 2012; Gustafson, 2014; Lewicka, 2014). Derfor drøftes heller ulike betydninger av sted i diskusjoner om hjemsted og flerstedstilknytning, om stedstilknytning og -identitet, stedsattraktivitet, stedlige innovasjoner og stedsutvikling, transnasjonale prosesser og forholdet mellom det lokale og globale. I mitt arbeid i møte med unge mennesker i Troms, er dette viktige og relevante perspektiver. Denne artikkelen gir ikke rom for å gå djupt inn i nyere stedsteori, men nevnte aspekter ser jeg på som sentralt for å peke framover i møte med utviklingstrekk i nord.

Begrepet flerstedstilknytning (Munkejord 2009) har jeg funnet inspirerende. Mange unge flytter for å ta utdanning og kan da både bo på flere plasser og oppleve tilhørighet til mer enn ett sted. Denne type perspektiv innebærer også at man kan ha flere og parallelle identiteter, og de kan også være tildels motstridende. Beck \& Beck-Gernsheim (Stenbacka 2012) har kalt dette stedspolygami. Et argument for å fokusere på flerstedstilknytning er det faktum at det åpner for andre måter å forstå samhandling mellom forskjellige steder en har tilknytning til. Massey (2005) legger til grunn et relasjonelt og dynamisk stedsbegrep som fremhever at steder skapes gjennom forbindelser, bevegelser og praksis. En ny generasjon vil ta i bruk teknologi, både i utdanning, læring og arbeid, på andre måter enn tidligere. Det åpner for nye måter å forstå steder, samtidig som deler av mange jobber kan løses stedsuavhengig.

Bakteppet, dvs. det statistiske materialet der en bruker kvantitative data fra SSB, gir ei tilnærming som Kalleberg (1992) definerer som et konstaterende forskningsparadigme. Tradisjonell forskning har ofte dette som utgangspunkt der forskeren er opptatt av ikke å 
påvirke paradigmet eller de det forskes på (Tiller 2006, Bjørnsrud 2005). En søker da å være mest mulig nøytral i forhold til aktørene og det studerte felt (Kalleberg 1992:31). Kalleberg skiller mellom konstaterende-, vurderende- og konstruktive forskningsspørsmål. I konstaterende spørsmål spør vi om hvordan og hvorfor noe er som det er, eller eventuelt kanskje kommer til å bli. I denne artikkelen er det, slik jeg ser det, viktig å få tak i unge framtidsstemmer fra nord som reflekterer videre ut fra et demografisk, konstaterende virkelighetsbilde. Unge har synspunkter og er opptatte av framtida i vår landsdel. Jeg ønsker å lytte til vurderinger unge har der de gir verdi til en sosial realitet (Kalleberg 1992:32). Kalleberg hevder at en da går over i nytt forskningsparadigme der en bruker vurderende forskningsspørsmål.

\section{Metodevalg}

Min empiri er hentet fra Troms, primært fra Midt-Troms. Innsamling av data til denne artikkelen er gjennomført med både kvantitative og kvalitative metoder. Først har jeg hatt en elektronisk spørreundersøkelse til alle ungdomsrådene i Midt-Troms og unge som er ansatte som trainee i denne regionen. Som en oppfølging og kvalitetssikring av disse data, er det gjennomført en workshop der ungdom, ungdomsarbeidere og ordførere deltok. Her ble funn fra den elektroniske spørreundersøkelsen presentert og drøftet. Videre er det gjennomført oppfølgingsintervju med 15 ungdommer. Disse er fra hele Troms. I hovedsak har det bidratt til både å kvalitetssikre data, analysere disse og også rette blikket framover for hva og hvordan en kan ivareta ungdommens synspunkter. Ved å bruke metoder på tvers, både kvalitative og kvantitative, er intensjonen at disse skal kunne utfylle og berike hverandre (Grønmo 2004; Jacobsen 2005). Tall fra spørreundersøkelsen har satt meg på sporet av flere gode samtaler, som har skapt dybde i analysene og generert ny kunnskap.

I første fase er det gjennomført en elektronisk undersøkelse der to grupper ungdom er valgt ut som informanter; ungdomsrådsmedlemmer ${ }^{1}$ og traineer ${ }^{2}$ tilsatt $\mathrm{i}$ bedrifter i regionen. 48 personer fra ungdomsrådene i alle åtte kommunene har svart og alle seks traineer har gitt sine

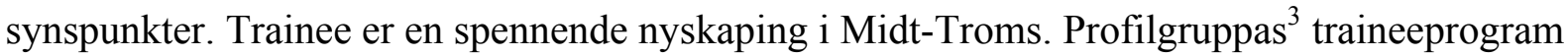

\footnotetext{
${ }^{1}$ Det er ungdomsråd i alle åtte Midt-Troms kommunene. Disse har ulik organisering og ulikt antall medlemmer.

${ }^{2}$ På aktuelt tidspunkt var det 6 traineer, og alle har svart.

${ }^{3}$ Profilgruppen i Midt-Troms er en sammenslutning av bedrifter og virksomheter innenfor nærings- og samfunnsliv i regionen. Gruppa har eksistert i over 20 år og har i dag 55 medlemsbedrifter med til sammen rundt 5.000 medlemmer. Majoriteten av bedriftene befinner seg innen industri og primærnæringer, men
} 
er åpent for alle nyutdannede kandidater fra høgskole eller universitet på bachelor- og masternivå, innenfor fagområder som er relevante for de vel femti medlemsbedriftene. Programmet startet i 2014, og nye kull tas opp hver høst.

I fase to er det gjennomført en workshop med fokusgruppesamtaler. Der deltok to ungdommer fra hvert ungdomsråd i åtte Midt-Troms kommuner sammen med ordførere og ansatte i kommunene som jobbet med ungdommer. Målet med workshopen var todelt. For det første var målet å følge opp og verifisere svar fra den elektroniske undersøkelsen. Ved at unge kunne ha dialog med politikere og ansatte i kommunene, kunne kvantitative data fra den elektroniske undersøkelsen i større grad analyseres i fellesskap. For det andre er det et ønske i Midt-Troms å etablere et regionalt ungdomsråd for å utvikle nytt samspill. I en større samfunnsanalyse (Storvoll, Alvig, Espenes \& Myrvoll, 2015) for Midt-Troms er det en erkjennelse av at en må jobbe strategisk mot ungdom der et regionalt ungdomsråd kan være et viktig verktøy.

Viken (2012) hevder at fokusgruppesamtaler egner seg for å finne fram til drivkrefter bak eller underliggende prosesser i samfunnsutvikling som bare kan identifiseres gjennom menneskelig persepsjon og fortolkning. Metoden har vist seg å være anvendelig $\mathrm{i}$ undersøkelser av stedsoppfatninger, stedsidentiteter og andre stedsrelaterte analyser. Folk vil gjerne diskutere sitt sted og har som regel tanker om hva som skjer der de bor. Unge i min undersøkelse viste stort engasjement i workshopen, ikke minst i møte med åtter ordførere. Her fikk de mulighet til å gi uttrykk for veivalg som de betraktet som viktige for framtida i MidtTroms. Ofte kombineres metoden fokusgruppesamtaler med dybdeintervjuer (Viken, 2012).

Etter å ha bearbeidet materialet fra den elektroniske undersøkelsen og workshopen, har jeg valgt å intervjue 15 ungdommer fra hele Troms, også noen tilhørende både i Sør-Troms og Nord-Troms. Som forsker ønsker jeg å utfordre på synspunkter unge har formidlet. Dermed bidrar andre unge i fortolkning. Intervjuene er gjort med ungdommer som var deltakere på Dyrøyseminaret $2016^{4}$. Målgruppa for ungdomssporet på Dyrøyseminaret var medlemmer av ungdommens fylkesråd i Troms, regionale ungdomsråd og andre. Felles for informantene som har deltatt i alle tre faser, er engasjerte ungdommer. I utgangspunktet vet en at medlemmer av

handel, bank, revisjon, forsikring, transport og reiseliv er også representert i tillegg til offentlige foretak, som kommuner i regionen, skoler og Forsvaret.

${ }^{4}$ Dyrøyseminaret er en stor nasjonal arena. Seminaret startet i 1998 og arrangeres annet hvert år. 
ungdomsråd ofte er bevisste ungdommer med initiativ og ønske om å bidra. Allerede i utgangspunktet vet jeg at utvalget av unge kanskje ikke er representativt. Dermed må også empirien sees på som noen meningsbærere for synspunkter som ikke alle deler. Det er viktig å tydeliggjøre at en må være forsiktig med å generalisere ut fra et for svakt empirisk grunnlag. Når dette forbeholdet er tatt, vil jeg likevel antyde at det er sannsynlig at det som gjelder for ungdom primært i Midt-Troms, også kan gjelde for større ungdomsgrupper, både i fylket og ut over i landsdelen.

Spørreundersøkelsen er sendt ut ved hjelp av et web-basert verktøy for utforming og analyse av spørreundersøkelser, kalt Beetrieve. Innledningsvis svarer respondentene på spørsmål om alder og hva de tenker å utdanne seg til. Ungdommene er deretter - på lik linje med politikere, næringsliv og andre - spurt om hvilke bransjer/næringer ${ }^{5}$ de har tro på i framtiden. De har også svart på hvilke hemmere og fremmere de tror kan påvirke økonomisk vekst.

Svaralternativene ungdommen har fătt er basert på et forarbeid med innspill fra flere parter, både politikere og næringsliv. Til slutt svarer de på hvorvidt de ser for seg å bo og arbeide i Midt-Troms i framtiden. Det er en svakhet i det elektroniske spørreskjemaet at det kun gis tre alternativer på dette spørsmålet. I ettertid er det prøvd å kompensere for denne svakheten ved at unge i fokusgrupper og også i intervju svarer med egne ord og refleksjoner.

\section{Empiriske funn}

48 medlemmer som representerer ungdomsrådene i Midt-Troms har svart ${ }^{6}$. Alle har ikke svart på alle spørsmålene, men jeg mener det gir en god indikasjon på trender. Alle respondenter er under 19 år, og ca. halvparten av de som har svart er ungdomsskoleelever (52 prosent) og halvparten (48 prosent) fra videregående skoler. Det gjenspeiler med forholdsvis stor grad av sikkerhet sammensetningen av ungdomsrådene i Midt-Troms. Alle som har svart bekrefter at de har vokst opp i Midt-Troms. Spørsmålet kan ha en mulig feilkilde i og med at alternativene bare var «ja/nei». Kanskje har noen av disse bare hatt deler av sin oppvekst i regionen, uansett kan en tolke at ungdommene definerer seg som hjemmehørende her.

\footnotetext{
${ }^{5}$ Basert på standard næringsgruppeinndeling fra SBB.

${ }^{6}$ Det er ungdomsråd i alle åtte Midt-Troms kommunene. Disse har ulik organisering og ulikt antall medlemmer, og derfor er det vanskelig å vite svarprosenten.
} 
Unge i Troms er opptatte av framtida og gir uttrykk for et stort engasjement. Selv om det ikke er like lett å lese det ut fra svar i det elektroniske spørreskjemaet, mener jeg også utsagn herfra viser det. Enda tydeligere blir det $\mathrm{i}$ fokusgruppesamtaler der flere unge tar til ordet for at de vil være med å påvirke framtida. Mange gir uttrykk for at de ser regionen og landsdelen som ei mulighet, samtidig er det relativt mange kritiske røster. Flere av disse hevder unge i for liten grad har medvirkning. «Hadde unge blitt tatt seriøst og fått lov til å komme med mer innspill i dagens politikk, hadde vi i større grad vært med å forme hele framtida vår, ikke bare de siste årene på skolebenken. Jeg tror det ville vært ei god investering for utviklinga i Troms» (Jente 16 år). I fokusgruppesamtalene følger to andre unge opp med å støtte utsagnet. En gutt på 17 år er klar i sitt syn. «Jeg skulle ønske at vi unge fikk lov til å fungere som bidragsytere. Det er ikke en realitet i dag» En ordfører utfordrer utsagnet fra 17-åringen ved å spørre hvordan det kan bli en realitet. Ei jente (18) svarer: «Jeg syns det er betenkelig at vi har et demokrati der vi unge ikke har fast representasjon i de fleste politiske fora». Gjennom fokusgruppesamtalen mellom ungdommer, politikere og ansatte utvikles en felles forståelse at det er viktig at unge blir hørt. «Det at vi har en felles workshop, er et godt grep for å ta ungdom på alvor. Blir vi lyttet til, kan vi ha arenaer som denne, er vi kommet et godt stykke på veg» (Jente 18 år).

Figur 1: Noeringer som har økonomisk vekstpotensial?

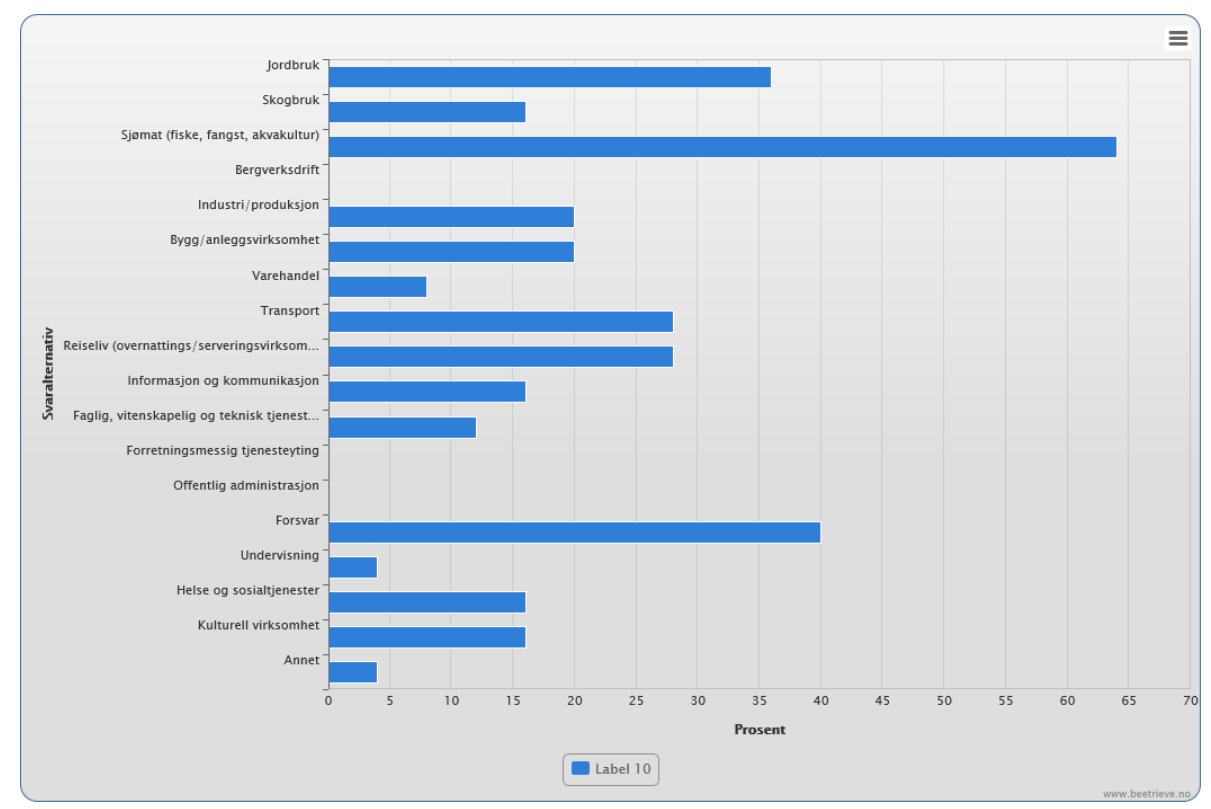

Ungdom i Midt-Troms betrakter sjømat som den næringen med størst vekstpotensial i regionen. «Sjømat (fiske, fangst, akvakultur)» utmerker seg ved at 64 prosent har valgt det 
som ett av tre alternativer som de kunne krysse av. Deretter følger «Forsvar» (40 prosent) og «Jordbruk» (36 prosent) som vekstnæringer. På de neste plassene kommer «Transport» (28 prosent) og «Reiseliv, overnattings-/serveringsvirksomhet» (28 prosent).

Slik kommenterer en 17-åring (gutt) data fra undersøkelsen: «Det skjer mye i vår region. Og jeg tror at vi unge også er i stand til å ta inn over oss at det er mange muligheter til jobb i framtida, f.eks. innenfor sjømat. Jeg har flere venner som enten er startet på blå utdanning eller som tenker å studere på Fiskerihøgskolen i Tromsø». Han får støtte av flere i fokusgruppesamtalene. «Jeg er enig, men samtidig er det viktig at en tar den utdanningen en har mest lyst til. Det er jo ikke så lett å vite hvor en kommer til å bo eller jobbe om 10-15 år», sier en jente (15 år). «Om en utdanner seg innenfor økonomi, eller som ingeniør eller noe annet, så kan en likevel ha sitt arbeid i flere bransjer», påpeker en gutt (19 år).

Figur 2: Faktorer som bidrar til god vekst?

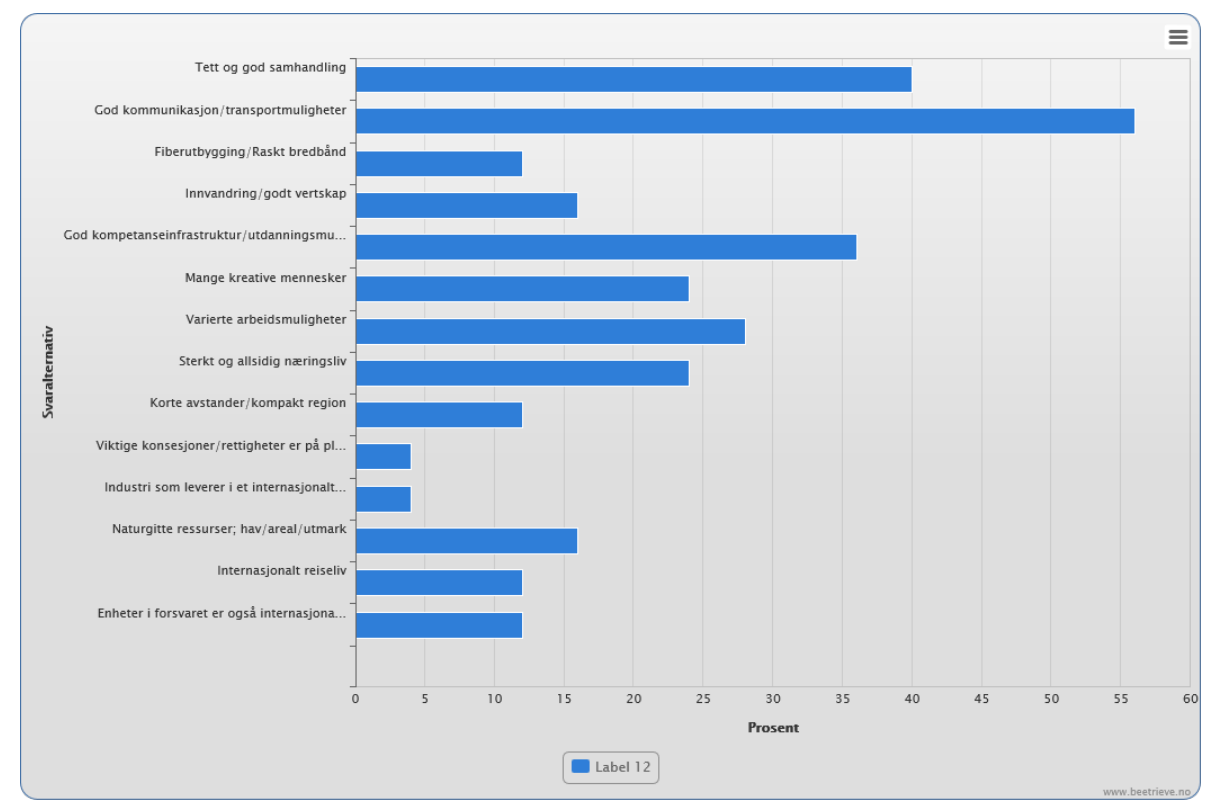

På spørsmål om hvilke faktorer som ungdom tror bidrar til god vekst i Midt-Troms har svaralternativene «God kommunikasjon/transportmuligheter» (56 prosent) og «Tett og god samhandling» (40 prosent) fått flest svar. Samhandling ble i en fokusgruppe forstått som «tidlig kontakt mellom aktører».

Rett bak følger «God kompetanseinfrastruktur/utdanningsmuligheter» (36 prosent) og «Varierte arbeidsmuligheter» (28 prosent). I fokusgrupper ble ungdommene utfordret på hva de oppfatter med svaralternativet «God kommunikasjon». Ulike typer kommunikasjon og 
infrastruktur ble trukket fram, både fiberutbygging og vei og kollektivtilbud. Begge deler må til for å møtes, mener ungdommene. Noen trekker fram at også internt i kommuner er det lange avstander. «Vi er helt avhengige av skyss av voksne fordi det kun går en buss hver dag til sentrum der jeg bor» (jente 16 år). Flere ungdommer var inspirert av modellen fra NordTroms, der de har vist at regional samhandling mellom ungdom er mulig å få til. «I NordTroms organiseres det møter i det regionale ungdomsrådet slik at ungdom reiser til møtestedet sammen med en voksen (ungdomssekretær), som samtidig har møte med sine kolleger fra de andre kommunene», sier en av lederne i regionalt ungdomsråd (jente, 17 år). «Det settes også opp gratis transport for ungdom fra hver kommune når store arrangement finner sted, eksempelvis konserter, rusfritt 16. mai-tilbud o. s. v.», forteller en annen (gutt 16 år).

«Å jobbe i lag er artig» sier en gutt på 17 år. «Jeg syns ikke vi tidligere har vært så god til det, verken ungdommene eller de som jobber i kommunene», fortsetter han. Flere gir uttrykk for støtte til synspunktet. «Skal det være attraktivt å slå seg ned her i framtida, vil samhold i regionen være viktig og at det ikke foregår en krangel mellom politikere til en hver tid» (gutt 18 år). Flere ordførere fulgte opp synspunktene som kom fram i samtalene i workshopen. En sa det slik: «Vi setter stor pris på ærlighet og at dere unge er så konstruktive. Vi har et felles mål om å være en attraktiv region, og da er det avgjørende at vi står i lag som team MidtTroms. Dette skal jeg ta med videre i arbeidet vi gjør i regionrådet».

Figur 3: Faktorer som hindrer god vekst?

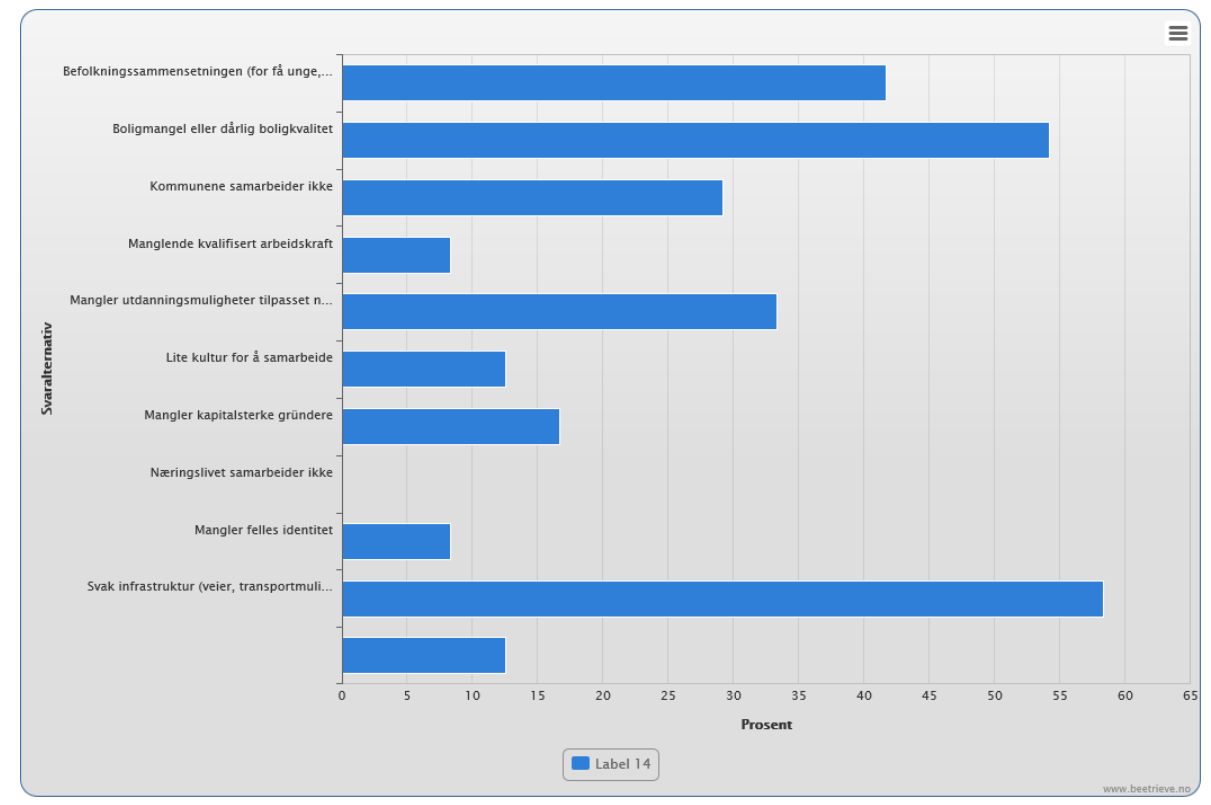


Når spørsmålet er motsatt formulert, altså hva ungdom tror hindrer god vekst, får vi utslag på «Svak infrastruktur, veier/transportmuligheter» (58 prosent). Deretter følger «Boligmangel eller dårlig bokvalitet» (54 prosent) og «Befolkningssammensetning, for få unge/svak vekst» (41 prosent).

På spørsmål om ungdommen planlegger å bosette seg i Midt-Troms etter endt utdanning, svarer så mange som 76 prosent «nei» eller «vet ikke» i den elektroniske spørreundersøkelsen. Fordelingen er 16 prosent på «nei» og 60 prosent på «vet ikke». Det er viktig å merke seg at over halvparten uttrykker ei usikkerhet som kanskje vil være naturlig for unge i denne fasen av livet. Svarene trenger ikke å være et klart uttrykk for at unge i framtida ikke ser regionen som attraktiv. I fokusgruppesamtalene og intervju senere, ble unge utfordret på å gi synspunkter på hvorfor så mange svarer slik. Ei jente (18) mener at synet på hva som er viktig endrer seg i løpet av ungdomstida. «Da jeg var 13-14 tenkte jeg at Troms ikke var plassen for meg. Her skjedde det lite. I dag ser jeg helt annerledes på det. Jeg tror det har sammenheng med at det kommer ut mange positive nyheter fra området». I intervju svarte en gutt på 16 følgende: «Det er viktig å bo i andre deler av landet først. Jeg tror det er mange som tenker som meg: først vil jeg ta ei utdanning, kanskje i en by sørpå, Oslo eller Bergen, så vil jeg høste erfaring med å jobbe og bo andre plasser før jeg flytter tilbake til nord. Men jeg ser for meg å sette nesen heimover etter noen år borte». Det er åpenbart forskjellige ståsted der mange er usikre på framtida og hvor de ser for seg å bo. Noen gir imidlertid klart uttrykk for at de opplever regionen som attraktiv. «Jeg ønsker å bo og jobbe i Midt-Troms. Her skapes mange arbeidsplasser og i denne regionen er det liten arbeidsledighet. Det betyr noe når jeg skal tenke framover», sier en gutt på 17 år.

I intervju er det mange som setter ord på det å reise bort for å studere. Så mange som 8 av 15 gir uttrykk for ønske om enten å jobbe eller studere i utlandet. Fokus hos flere er rettet mot ønsket om å være en del av en global verden. «Det er viktig å bli god i språk, og jeg har lyst til å bli en internasjonal borger» (jente 16 år). En gutt på 17 år sier at «økt samarbeid internasjonalt gjør at jeg tenker at også jeg vil enten studere eller bo i utlandet en periode». Flere bruker utsagn som dette; «Jeg har lyst til å studere i utlandet, men kommer til å bosette meg i Nord-Norge» (jente 17 år).

Samtidig er flere av ungdommene tydelig på at det er vanskelig å være skråsikker på valg framover. En jente på 18 år sier det slik: «Planene er ikke helt klare. Jeg vil ikke ha så 
skråsikre planer framover, det er ikke noen vits i, de vil endres uansett. Tida og impulser vil vise hva framtida vil bringe».

Ungdom i Troms uttrykker at de også er bekymret for miljøet. Dette gjelder både i havet, men også slitasjen på naturen. «Vi må lære av det som har skjedd i Lofoten», sier en gutt på 18 år. «Der er slitasjen på natur og fjell for stor. I tillegg er søppel i naturen blitt et økende problem» Han stiller også et retorisk spørsmål: «Er det slik at masseturisme er noe vi ønsker? Burde vi ikke være med å styre veksten vi ser i reiselivet». Spørsmålene rettes mot alle ordførerne. Flere nikker bekreftende. «Vi har satt i gang et felles arbeid på bærekraftig reisemålsutvikling i regionen», svarer en. Flere unge tar til ordet for at ensidig forståelse av vekst som noe positivt, ikke stemmer. Ei jente (17 år) uttrykker det slik: «Det er jo kjempebra at det skjer mye i Nord-Norge, men jeg syns vi er for opptatte av vekst på bekostning av ei god og trygg utvikling. Altså, jeg mener at vi må klare og samtidig tenke på at vi ta hensyn til miljøet, det gjelder både i havet og i naturen på land. Bærekraft er etter mitt syn et ord som kanskje har lite innhold». I fokusgruppesamtalene utvikles en viktig og stor dialog om vekst også kan en negativ slagside. «Forurensning hindrer vekst $\mathrm{i}$ vår landsdel, slik jeg ser det. Det som er lurt og lønnsomt på kort sikt, kan få det motsatte resultatet på lengre sikt. Derfor må vi ikke drifte havet for hardt. Jeg er skeptisk til oljeutvinning og jeg syns vi har for mange oppdrettsanlegg» (Gutt 18 år).

Ungdommene ble til slutt bedt om å gi regionen noen gode råd. I den elektroniske spørreundersøkelsen ble det gitt mange og varierte innspill; gode jobbtilbud/kunnskap om arbeidsplasser, omdømmebygging, kultur- og fritidstilbud/aktiviteter, skape trygge samfunn, arbeidsplasser, barnehagetilbud/gode skoler, satse på utdanning/bredere utdanningstilbud i regionen/alternative studietilbud, bolig/studentbolig og utvikling.

\section{Undersøkelse blant trainee}

Også blant respondentene som arbeider som trainee i Midt-Troms har alle tro på bransje/næring «Sjømat». De skiller seg likevel fra de yngre ungdommene ved at like mange har tro på «Industri/produksjon» og mange velger også «Reiseliv, overnattings/serveringsvirksomhet». Alle er utdannet som ingeniører og økonomer og jobber i industribedrifter, det er derfor ikke unaturlig at de er opptatt av bransjer de kjenner godt. 
På spørsmålet om hvilke faktorer som fremmer vekst har fem svaralternativer fått 50 prosent score: «Tett og god samhandling», «God kommunikasjon/transportmuligheter», «God kompetanseinfrastruktur/utdanningsmuligheter», «Sterkt og allsidig næringsliv»og «Naturgitte ressurser, hav/areal/utmark», altså ganske likt ungdommene sine svar. De tre førstnevnte faktorene har ungdommene i ungdomsråd også tatt med, bare med litt ulik vekting.

Faktorer som hindrer vekst er ifølge de fleste traineene «Befolkningssammensetning, for få unge/svak vekst», «Mangel på kvalifisert arbeidskraft» og «Mangel på felles identitet». Her skiller svarene seg fra de yngre ungdommene, som var mer opptatte av infrastruktur og bolig.

En stor andel av traineene, 4 av 6, er usikre på om de vil bosette seg i Midt-Troms etter trainee-perioden. Flere av traineene gir innspill på hva som må til for at de og andre vil velge å slå seg ned i Midt-Troms: Relevant arbeid for seg selv og sin partner, gode bomuligheter, faglige videreutviklingsmuligheter og kvalitet $i$ barnehage, skole og fritidstilbud for egne barn påpekes som viktige faktorer. Det er naturlig at traineene som er litt eldre, er mer opptatte av familierelaterte spørsmål og muligheten for arbeid for sin partner/medflytter.

\section{Diskusjonsdel}

I diskusjonsdelen ønsker jeg å drøfte funn fra egen empiri, men også noen andre undersøkelser. Arbeidsplasser og næringsutvikling er avgjørende for at unge velger å vende tilbake fra utdanning i mer urbane steder. Her vil jeg særlig vektlegge noen utviklingstrekk i Midt-Troms innen sjømat og ei god oppbygging av et større traineeprogram. Fra 2017 vil vel 20 unge traineer med høy kompetanse være tilsatt i bedrifter i Midt-Troms.

\section{Kampen om de unge}

I mine undersøkelser forteller mange unge at de reiser fra sitt hjemsted, primært for utdanning, men også for jobb og andre opplevelser. Dette er naturlig, mens det er et tankekors at så mange sier enten «nei» eller «vet ikke» om de skal flytte tilbake (76 \%). Det handler ikke bare om hender, men også om hoder. Nå er det viktig å understreke at mange tenåringer svarer ut fra at de ikke vet noe om framtida, og dermed er svarene usikre. Likevel er det en indikasjon som gir grunnlag for refleksjon. Det er ikke bare et problem at det blir 
færre som kan ta roller og gå inn i ny jobber i Troms, men utfordringa er også tap av kompetanse og innovasjonskraft. Det er alvorlig om unge med høy utdanning i mindre grad vil bruke sin kunnskap i landsdelen. Min forskning bekrefter tidligere forskning på fagfeltet. Leknes m fl (Leknes, Tønnessen \& Syse, 2016) dokumenterer i sin forskning at en stor andel unge som reiser ut fra nord, ikke vender tilbake. Sørlie (2006) viser til at flyttestatistikker forteller at unge voksne mellom 20-29 år er den mest mobile aldersgruppen. Det er en fase av livet som ofte kalles søkefasen; der det ikke bare er utdanning og yrkesliv som utforskes, men også for eksempel nye bekjentskaper, nye steder og nye opplevelser. Det handler om å ta stilling til tre typer spørsmål i følge Sørlie (2006): Hva skal jeg gjøre her i livet? Hvem skal jeg gjøre ting sammen med? Hvor skal det skje? Det første knippet spørsmål omfatter faktorer som har med utdanning og yrkeskarriere å gjøre, og også ting som kan være relatert til interesser og hobbyer. Hvem-spørsmålet er knyttet til familiedannelse og barn, men også til andre sosiale bånd og nettverk. Hvor-spørsmålet har med stedsfølelse og stedsidentitet å gjøre. Svarene og prioriteringen mellom disse spørsmålstypene har implikasjoner for framtidig bosted.

Det er relativt flere fra distriktskommuner og småbykommuner enn fra storbynæreområder som flytter i løpet av denne søkefasen. Det unge fra Midt-Troms sier stemmer godt med livsløpsanalyser utført av Kjetil Sørlie (2006) som bl.a. viser at 70-75 prosent av de som er oppvokst i distriktskommuner og 65-70 prosent av de som er oppvokst i småby/tettstedskommuner, flytter fra denne kommunen minst én gang før de har fylt 35 år. Tilsvarende for storbyene er 60 prosent. I motsetning til distriktskommuner og småbykommuner blir imidlertid de som flytter fra storbyene erstattet, og vel så det, av nye innflyttere. Disse tallene har vært relativt stabile over tid.

Det er ikke vanskelig å forstå at ungdom i alderen 13-19 år ikke vet hvor de skal bo og jobbe i framtiden. Det er naturlig å reise ut og høste erfaringer før man etablerer seg. Å fremstå som en attraktiv region, er viktig, både for kommuner, offentlig sektor og næringsliv. I fokusgruppesamtaler var mange opptatte av å følge opp ungdommen som reiser ut; hvordan skal man holde kontakten med utflyttede ungdommer i perioden de bor utenfor regionen, hvilke kanaler er gode kanaler for dialog og på hvilke arenaer kan man møte ungdommene igjen? Hva er viktig for de som vurderer å vende tilbake? I lys av det som er sagt kan det være et godt poeng å arbeide med regionens omdømme, samt prioritere felles markedsføring. 
Det er tydelig at ungdom helt fra grunnskolealder tenker på framtiden og hva som er viktig når man skal etablere seg med bolig og familie. Svar i fokusgruppesamtalene tyder på at ungdom vil tilbake til det trygge, «det kjente», når de skal etablere seg. Når ungdommene ble bedt om å reflektere over hvorfor så få var sikre på at de skulle bo og arbeide i regionen, kom det blant annet frem at Midt-Troms ble oppfattet som «trygge omgivelser», men med mangel på yrkesmuligheter. Ungdom etterlyste muligheten for å leve et «mer urbant liv» i MidtTroms med flere møteplasser for ungdom. For en region med ambisjoner om å rekruttere unge, er dette verdt å ta med seg i utarbeidelsen av tiltak og strategier videre.

Rees og Kupizsewki (Rees \& Kupizsewki 1999) viser til at det er de unge som driver sentraliseringen i Norge. I mange andre land vi liker å sammenlikne oss med blir de unges sentraliserende flyttemønster kompensert ved at eldre aldersgrupper flytter ut av de store byene. Her i landet ser vi denne tendensen kun i storbyenes nærmeste omland (Grimsrud, 2011). I tillegg virker det sentraliserende at flere og flere barn blir født i storbyene som følge av den store innflyttingen av unge voksne. På grunn av dette vil sentraliseringen fortsette selv uten flytting. Distriktene er således tapere i dobbelt forstand. Dette demografiske faktum gjør at det å satse på å tiltrekke seg unge mennesker er avgjørende.

Unge i Midt-Troms flytter i stor grad for å ta utdanning. Faktisk er det slik at mange allerede rett etter ungdomsskolen flytter på hybel. En viktig årsak til at det er større fraflytting fra distriktskommuner og småbyområder er at ungdom som vokser opp på slike steder, må flytte til de store byene for å ta utdanning (Fosso \& Belsnes, 2004). Når flere og flere unge tar lang utdanning ved universiteter og høyskoler, betyr det at stadig flere etablerer et faglig og sosialt nettverk på studiestedet som i sin tur gjør det lett å bli boende der. Svært ofte etableres de i parforhold som kan gjøre det enda vanskeligere å flytte fra studiestedet; særlig til små steder der det er vanskeligere å skaffe to utdanningsrelevante jobber samtidig. Det er ikke nødvendigvis slik at de unge aktivt velger bort distriktene - det kan like gjerne være at de blir «fanget» av storbyene fordi det enkleste er å bli boende. Så lenge mulighetene for jobb og karriere (for to) er på plass, er det lettere å fortsette det livet de lever, enn å bryte opp. I parforhold er det dessuten ofte slik at den ene blir ferdig med studiene før den andre. Da tar den ene jobb lokalt i påvente av at den andre blir ferdig, og dermed er man et skritt lenger i å etablere bofasthet på studiestedet. 
Flere undersøkelser viser at mange som bor i storbyområdene ønsker å flytte tilbake dit de kom fra eller til andre mindre steder, men at manglende jobbmuligheter står i veien for dette (Orderud og Onsager 1998, Grimsrud 2005). Mange unge i Midt-Troms er usikre, naturlig nok, på om de skal flytte tilbake til regionen de har vokst opp i. Selv om det er på det rene at det ikke er like mange arbeidsplasser for høyt utdannende utenfor de store byene, kan det også handle om at mange ikke har nok kjennskap til de jobbmulighetene som finnes, eller at de bruker manglende jobb som en kort og legitim forklaring på at tilbakeflytting ikke er aktuelt (Grimsrud, 2000). Hansen (Hansen, 2004) har for eksempel pekt på at utdanningsaspirerende ungdom, som vokser opp på såkalte ensidige industristeder, lenge etter at hjørnesteinsbedriften er nedlagt og erstattet av kunnskapsintensive arbeidsplasser, fortsatt tror de må flytte fordi bygda ikke har utdanningsrelevante arbeidsplasser å tilby. I nord skapes det mange nye arbeidsplasser. Selv om ungdom i denne undersøkelsen hadde bevissthet om dette, er en del av de nye jobbene ikke så etablerte og en refleksjon kan være at unge ikke ser seg selv inn i disse.

Mange distrikt lider under et negativt stedsimage som forteller at det ikke fins utdanningsrelevante jobber der. Måten et sted presenteres på i media, i skjønnlitteratur så vel som faglitteratur, er av betydning for hvordan vi oppfatter et sted og dermed også for hvordan vi forholder oss til det. Når det gjentatte ganger fortelles om bygder og småsteder som mister sine ungdommer gjennom fraflytting, som har en økonomi preget av næringer uten vekst og som sakker etter i utdanningssamfunnet, så skaper dette et stedsimage, et kollektivt meningsfellesskap, som sier at dette ikke er steder for folk med høy utdanning. Dette bekreftes av flere i intervju. «Jeg visste ikke at det skapes så mange nye og forskjellige arbeidsplasser i sjømat» sier bl.a. ei jente på 18 år. Hennes utsagn kan være en indikasjon på hvor lett det er at stedsmyter fungerer som kulturelle sannheter og antas å ha stor innvirkning på hvilke steder unge mennesker i det hele tatt vurderer som aktuelle bosteder (Haugen \& Lysgård, 2006). Dette er en hovedgrunn til at mange steder de senere årene har hatt fokus på omdømmebygging; de har jobbet aktivt for at deres område skal identifiseres med noe positivt (Niedomysl, 2004). Det er etterhvert eksempler på at steder har lykkes med å endre sitt image, og at dette trolig også har ført til befolkningsvekst eller økonomisk vekst (Teigen og Lønning 2009). Det handler om å gjøre gamle myter til skamme gjennom å overskride dem. For eksempel vil en regional trainee-ordning kunne bidra til å bekjempe forestillingen om at det ikke finnes relevante arbeidsplasser for unge med høy utdanning på stedet, dels gjennom å profilere bedriftene/virksomhetene og stedet, men ikke minst gjennom at bedriftene faktisk 
ansetter denne gruppen slik at de motbeviser gamle stedsmyter og bygger nye. I dag (2017) er vel 20 traineer ansatt i bedrifter i Midt-Troms-regionen. De fleste har en masterutdanning, og alle er under 35 år. Dette synliggjør en aktiv næringsstrategi som fungerer.

\section{Unge har god kunnskap om næring i nord}

Nærmere 50 ungdommer har i svart på hvilke næringer som har størst vekstpotensial og hva som bidrar til vekst og hva som hindrer vekst. Det er rettet samme spørsmålsstillinger til voksne, både politikere og næringsliv. Ungdom og voksne svarer svært likt. Det kan tyde på at også unge i aldersgruppa 13 -19 år har god kunnskap om vekstnæringer og hva som hemmer og fremmer vekst. Samtidig er det interessant at det er lite samsvar mellom hva ungdom anser som vekstnæringer og hva de har tenkt å utdanne seg til. Kun én ungdom har valgt et framtidig yrke som tyder på at vedkommende vil jobbe i sjømatnæringen. En kan hevde at det er lite korrelasjon mellom den kunnskapen ungdom har skaffet seg og de eventuelle følgene dette får for videre valg.

Det kan være flere grunner til at undersøkelsen viser at det er lite samsvar med vekstnæring og utdanningsvalg. En hovedgrunn er at de fleste ungdommene som har svart, allerede er i videregående skole og følgelig har tatt sitt valg. I fokusgruppesamtaler i etterkant av den elektroniske undersøkelsen, påpeker flere ungdommer at det tar tid for at ny kunnskap får konsekvenser for ungdoms valg både om utdanning og senere jobb. Når man våren 2017 ser søkertall til blå linje på videregående skole i Troms, det vil si utdanningsprogrammet som forbereder elever for yrker innen fiske, fangst og akvakultur, kan det se ut som om større endringer er i emning. Ungdom velger blått. Aldri har så mange søkt blå linje som førstevalg i Troms. Det opprettes en ekstra klasse for å ta ivareta valg for utdanning. For utviklingen i nord kan dette være gode nyheter. Først og fremst fordi sjømatbransjen er ei framtidsrettet næring og en viktig bærebjelke i samfunnsutviklinga. Omsetningen har økt formidabelt i løpet av få år. I 2106 vil Senja-regionen alene omsette for seks milliarder kroner i sjømat. Prognosen framover indikerer videre økning og forteller at behovet for fagkompetanse er stort.

I fokusgruppesamtale etter undersøkelsen kom det frem at flere ungdommer oppfattet kategorien «sjømat» som «oppdrett», ikke fiske og fangst. Å jobbe innen tradisjonelt hav og fjordfiske ble av enkelte sett på som en «arv», ikke et aktivt yrkesvalg. Noen grupper 
kommenterte at satsing på sjømat ga mange nye muligheter innenfor yrker som advokat, ingeniør osv. Ungdommene skilte tydelig mellom teknisk produksjon, salg/markedsføring og øvrige oppgaver knyttet til sjømatproduksjon.

Av de 48 ungdommene som svarte i undersøkelsen, planlegger så mange som 40 \% å utdanne seg innenfor yrker knyttet til helse. I følge SSB vil folketallet i Midt-Troms fram mot 2030 øke med ca. 3000. Nesten all økning vil komme i aldersgruppa over 67 år. I offentlig sektor, også i denne regionen, vil det være helse som har behov for arbeidskraft.

Forsvaret ble omtalt som en arena av muligheter, også for jenter, og forsvaret er tydeligvis oppfattet som en ressurs for Midt-Troms. «Stabile arbeidsmuligheter i Forsvaret» ble trukket fram av én gruppe, «mange utdanningsmuligheter» og «rekruttering til utenlandstjeneste» likeså.

Ungdommene har mer tro på jordbruk enn andre informanter, dvs. voksne, politikere og næringsliv. Ungdom trakk frem at vi i Midt-Troms har mye plass/areal og at dette burde kunne utnyttes til matproduksjon. En gruppe hadde reflektert rundt «Industri» som havner et stykke ned på rangeringen. Her ble det sagt at ungdom burde få mer kunnskap om de mulighetene som er i regionen, samt at yrkesfagene må gjøres mer attraktive.

Det ble også en diskusjon i en av gruppene for/mot jernbane. Ungdommene mente tydeligvis at jernbane kunne påvirket deres holdning til hva som er mulig å drive med i vår region. Ungdom er opptatt av botilbud, lenge før de selv skal etablere seg i egen bolig. Stort utslag på «boligmangel» kan også bety mangel på egnede boliger til målgruppen. Regionen er preget av lite variasjon i type boliger, og et boligmarked med lite omsetning. De fleste boenheter er eneboliger tilpasset større familier. Hvis regionen skal være attraktiv for studenter, traineer og nyutdannede, må det bygges mer varierte boliger tilpasset ulike livsfaser i Midt-Troms.

\section{Glokale $^{7}$ unge også i Troms}

Vel halvparten av ungdom jeg intervjuet, ønsket å ta utdanning i utlandet. Samtidig som de uttrykte verden der ute var viktig, påpekte de at hjemstedet også var viktig. «Jeg vil alltid

\footnotetext{
${ }^{7}$ Roland Robertson skapte i 1992 ordet glokalisering for å karakterisere de prosessene som pågår. Lokal identitet blir ofte mobilisert når folk møter globaliseringen fordi folk ønsker å understreke sin særegenhet når den trues
} 
bruke «heim» om plassen jeg vokste opp, selv om jeg planlegger å ta medisin i utlandet», sier ei jente på 17 år. Lokal tilhørighet og global tilkobling er sentralt for mange. Det er interessant å registrere at ungdommer i Troms snakker uproblematisk om dette.

Det er et velkjent faktum at betydningen av jobb er av større betydning som flyttemotiv for folk med høyere utdanning og akademiske yrker enn for andre; det bekreftes også av den nasjonale Flyttemotivundersøkelsen 2008. I et livsløpsperspektiv er jobb viktigst som flyttemotiv med én gang man er ferdig med utdanningen. Mange lar utelukkende jobben styre hvor de bosetter seg i denne fasen (Hansen og Niedomysl, 2009). Etter hvert som man blir eldre, kommer som regel andre flyttemotiv mer og mer inn i bildet. Da har man også opparbeidet seg en sterkere posisjon i arbeidsmarkedet slik at andre faktorer, for eksempel knyttet til stedstilhørighet, familieforhold og kulturtilbud kan få telle mer med i beslutningsprosessen. Det er forholdsvis vanlig med hyppige jobb- og bostedsskift i fasen som ung voksen. Man kan derfor vente at selv om traineene får jobb og blir boende i de aktuelle regionene etter endt trainee-periode, så er sannsynligheten stor for at de flytter videre etter en stund.

Selv om jobb og karriere ofte er den viktigste grunnen til at nyutdannede flytter, er jobbrelaterte forhold generelt på vikende front som dominerende flyttemotiv (Lundholm, Garvill, Malmberg \& Westin, 2004). Dette gjelder særlig i Norge hvor arbeidsledigheten har vært lav gjennom lang tid og hvor arbeidsledigheten heller ikke varierer så alt for mye mellom ulike regioner. Når det er tilgang på jobb nær sagt over alt, og når unge med høy utdanning er en mangelvare, så kan de unge i større grad tillate seg å la andre kriterier bestemme bostedsvalget. I flyttemotivundersøkelsen var for eksempel familierelaterte forhold det hyppigst nevnte motivet. I unge år er det særlig snakk om flytting på grunn av kjæresteforhold. Frønes og Brusdal (Frønes \& Brusdal, 2001) har kalt dagens unge for «friends-generasjonen». Med det mener han at dagens unge legger mer vekt på å kunne være sammen med, og bo nær, venner enn familie. Dette er en generasjon som i mindre grad legger vekt på karriere og i større grad lar fritid og sosiale sider ved livet styre bostedsvalg. Dette er en utvikling som favoriserer utdanningsstedene som bosted for de unge, men understreker samtidig at det å satse på de sosiale sidene ved trainee-stillingene er viktige. 


\section{Trainee som strategisk grep}

Regionale traineeordninger er et relativt nytt virkemiddel. De fleste traineeordningene i Norge er etablert etter 2005. Kompetansesenteret for Distriktsutvikling (Dahle, Grimsrud \& Holte, 2011) har gjennomført en stor undersøkelse på hvilke effekter ni regionale trainee-ordninger har på målsettingen om å rekruttere unge med høy utdanning til distriktene. Flere funn er interessante og relevante for vår region. I Midt-Troms startet trainee-programmet i 2014 med 6 nyutdannede studenter. Etter to år som trainee i bedrifter i regionen, fikk alle tilbud om fast jobb. Videre er nye kull starta og fra høsten 2017 vil til sammen over 20 unge med høy kompetanse ha startet sin jobbkarriere i en regional bedrift. Undersøkelsen fra Kompetansesenteret for Distriktsutvikling sier at nær tre firedeler av bedriftene mener traineeordningen gjør det mulig å satse på nyutdannet arbeidskraft (Dahle m.fl., 2011). Over halvparten av virksomhetene som er med i regionale traineeprogram oppgir at ordningen har bidratt til å rekruttere kompetanse bedriftene ellers ikke ville ha fått tak i. Videre viser undersøkelsen at over seksti prosent av bedriftene mener traineene har bidratt til innovasjon og nytenkning gjennom at deres kompetanse har ført til nye prosjekter, produkter eller tjenester. Det vises til at to tredjedeler av de som har vært gjennom et traineeprogram har blitt boende i regionen, mens bare en fjerdedel bodde der i utgangspunktet.

\section{Oppsummering, videre forskning og utsyn}

Ungdom i Troms er sannsynligvis ikke så forskjellige fra ungdom fra andre mindre steder i landet. Mange unge flytter for å ta utdanning. En stor andel i min empiri er usikre på om de kommer tilbake for å bo og jobbe i den regionen de vokste opp i. De har relativt god kunnskap om næringslivet og hva som fremmer og hemmer vekst.

Unge skal, som generasjoner tidligere, gjøre selvstendige valg for egen framtid. Gjennom teori og empiri, ikke minst i fokusgruppesamtaler og intervju med unge i Troms, ser jeg flere mulige nye forskningsområder. Medvirkning av unge er et stikkord og et stort fagfelt. I fokusgruppesamtalene var bærekraft, vekst og ivaretakelse av miljøet viktige utviklingsperspektiver for de unge. Videre er samarbeid, og da i en global kontekst, er et annet interessant forskningsområde. Svært mange unge i Troms er opptatte av internasjonalisering. Mange gir uttrykk for at de vurderer å studere i utlandet. De glokale unge betrakter samhandling med andre land og kulturer som vesentlig i et framtidsperspektiv. Det 
er gjort lite forskning på demokratisk deltakelse og innflytelse fra unge i nærings- og lokalsamfunnsutvikling (Frøyland, 2011). Kvalitativ forskning der unge er sentrale bidragsytere, vil kunne gi ny kunnskap i planlegging, strategier og utviklingsarbeid for framtid, både i Troms og landsdelen. I møte med engasjerte og reflekterte ungdommer ble jeg som forsker utfordret på ei problemstilling jeg ønsker å ta med videre. En gutt på 17 år ga klart uttrykk for sitt syn og kan kanskje være talsperson for flere: «Unge vil delta! Unge vil påvirke! Unge vil bestemme!» Svaret hans var i en kontekst knyttet til framtid i nord. På flere måter samler guttens utsagn essensen i artikkelen. Jeg vil peke på tre viktige grep som kan oppsummere artikkelen og rette blikket framover.

For det første er det viktig å forstå hvordan forskning har gitt ny kunnskap om utvikling av steder. Små og større steder kan også endres ved at de betrakter glokale ungdommer som en ressurs som henter impulser ute og bidrar til ny kunnskap ved å koble eksterne, globale impulser med lokal identitet (Massey, 2005). For det andre synes det som et godt grep i den videre forskningen å gi aksjonsforskning en noe større plass. Ved å stille konstruktive forskningsspørsmål og bevege seg over i det Kalleberg (Kalleberg, 1992) kaller det konstruktive forskningsparadigme, vil unge få nye sjanser til å være aktører og aktive medspillere i samfunnsutviklingen på nye måter. Og for det tredje bør unge få større reell innflytelse i lokalsamfunnsutviklingen der de bor.

Steder endres, ikke minst av impulser utenfra. Massey (Massey, 2005) hevder det er viktig å se på steder som åpne og progressive der ytre stimuli bidrar til å redefinere sted. Når ungdommer reiser ut, linkes det globale og lokale sammen. Dermed kan glokale, unge fra Troms være sentrale aktører for å integrere og smelte sammen internasjonale impulser med lokal stedsidentitet. Det kan være en av gevinstene med at flere av oss i framtiden vil ha tilknytning til flere steder. Å gjøre videre forskning på dette fagfeltet, tror jeg vil være viktig. Å forstå mer av hvordan globale impulser redefinerer steder som igjen kan skape ny attraktivitet, tror jeg er både interessant og framtidsrettet. Unge vil være de sentrale aktørene i nye arbeidslivet. Selv om mange vil bo og arbeide i en annen del av landet, eller verden, vil ny teknologi og annen organisering av arbeidslivet gjøre det mulig å bidra med en rekke arbeidsoppgaver stedsuavhengig. For ungdom er det særlig viktig at regionen har en åpen holdning slik at unge mennesker kan betraktes som en ressurs, uavhengig av hvor en bosetter seg. 
I starten av artikkelen ble det referert til Kallebergs (1992) tre forskningsparadigmer, der han skiller mellom konstaterende-, vurderende- og konstruktive forskningsspørsmål og sier at konstruktive spørsmål dreier seg om hva ett sett aktører kan og bør gjøre for å omforme en gitt sosial realitet til en bedre sosial realitet. Gjennom dialog og innspill fra flere ungdommer, ser jeg potensialet av konstruktive forskningsspørsmål og aksjonsforskning i den videre forskningen. I siste del av doktorgradsarbeidet har jeg valgt å aktivere og realisere ideen om et forskende partnerskap med et utvalg ungdommer, politikere og næringsdrivende. De ideer, særlig ungdommene har kommet opp med i de undersøkelsene som hittil er gjort, ansporer til et aksjonsforskningsopplegg i det videre arbeidet. Som Galtung (2008) understreker, så preges aksjonsforskning av at et bestemt sett av verdier ligger til grunn for arbeidet.

Positivismedebatten avdekket at ingen forskning er verdifri, heller ikke den konstaterende. Likevel vil man kunne si at aksjonsforskning er annerledes ved at den bevisst og åpent tilkjennegir sine verdier, og videre at forskerne med viten og vilje intervenerer i søken etter det beste handlingsresultatet.

Forskjellene mellom tradisjonell forskning og aksjonsforskning belyses av Tiller (2006, s. 12), der han skiller mellom tre ulike forsknings- og utviklingsparadigmer. I det første paradigmet står forskeren langt borte fra sitt forskningsfelt og legger ikke vekt på å påvirke det eller de det forskes på. Det kreves kjølig distanse. I det andre paradigmet har forskeren beveget seg inn i feltet og forskere fra innsiden, eller tar et indre perspektiv. Forskeren er likevel i dette paradigmet også opptatt av ikke å påvirke det eller de det forskes på (Bjørnsrud, 2005, s. 14). Det tredje paradigmet innebærer blant annet at man kan bedrive forskning gjennom å intervenere og å forske sammen med praktikerne, noe Tiller (2006) betegner som det forskende partnerskap. De to første paradigmene kan grovsorteres under tradisjonell forskning, men det tredje paradigmet tilhører aksjonsforskning.

«Unge er framtida», sies ofte, muligens uten å gi tydelig innhold til utsagnet. Et viktig grep for Troms spesielt, men resten av regionen og landet generelt, er å ta unge på reelt alvor. Medbestemmelse er mer enn å lytte til hva de unge er opptatte av. Medvirkning består av to uavhengige, men samtidig innbyrdes avhengige prosesser, nemlig økt deltakelse og innflytelse. Medvirkningsarenaer på samfunnsnivå handler om å gi barn og unge mulighet for å påvirke beslutninger om og i lokalsamfunn og nærmiljø. Flere forskere (Winsvold \& Falck, 2011; Frøyland, 2011) viser til at unge har lite direkte påvirkning i offentlige medvirkningsprosjekter og i lokalsamfunnsutvikling. Å gjøre grep der unge i større grad, også 
sammen med etablerte forskere, bidrar i prosesser og planer for utvikling av sin region, kan være ei mulighet for innflytelse, eierskap og sterkere tilhørighet som kan vise seg viktig for framtiden i hele landsdelen. 


\section{Referanser}

Bjørnsrud, H. (2005). Rom for aksjonslæring: om tilpasset opplæring, inkludering og læreplanarbeid. Oslo: Gyldendal Norsk Forlag.

Castells, M. (1996). The Rise of the Network Society. Oxford: Blackwell.

Castree, N. (2003). Place: Connevtioens and boundaries in an interdependent world. I. S. L. Holloway, S. P. Rive \&G. Valentine (red.), Key Consepts in Geography (s. 165-185). London: Sage.

Dahle, M., Grimsrud, G. M., Holte, I. C. (2011). Bosettingsvirkninger av regionale traineeprogram. Ideas2evidence rapport 1/2011.

Fosso, O. B. \& Belsnes, M. M. (2004). Short-term Hydro Scheduling in a Liberalized Power System. Powercon 2004. IEEE/NTU/NSU; Singapore. 2004-11-21 - 2004-11-24.

Frønes, I. \& Brusdal, R. (2001). På sporet af den nye tid, kulturelle varsler for en noer fremtid. Gyldendal.

Frøyland, L. R. (2011). Unges syn på deltakelse og innflytelse i skolen, lokalpolitikken og sivilsamfunnet. Oslo: Norsk institutt for forskning om oppvekst, velferd og aldring. Vedlegg til NOU 2011: 20. Ungdom, makt og medvirkning.

Galtung, J. (2008). 50 years. 25 intellectual landscapes explored. Publications from Transcend University Press 3.

Giddens, A. (1991). Modernity and Self-Identity. Self and Society in Late Modern Age. Oxford: Stanford University Press California.

Grimsrud, G. M. (2000) Kvinner på flyttefot. ØF-rapport 2000/13.

Grimsrud, G. M. (2011). How Well Does the „Counter-Urbanisation-Story ${ }^{\text {ee }}$ Travel to Other Countries? The Case of Norway. POPULATION, SPACE AND PLACE. DOI: 10.1002/psp.655.

Grønmo, S. (2004). Samfunnsvitenskaplige metoder. Bergen: Fagbokforlaget.

Hansen, J. C. (2004). Ungdoms forhold til sted. Er Rjukan et blivende sted? I Berg et al (red): Mennesker, steder og regionale endringer. Tapir.

Hansen, H. K., \& Niedomysl, T. (2009). Migration of the creative class: evidence from Sweden. Journal of Economic Geography. Volume9, Issue2, Pp. 191-206.

Haugen, M. \& Lysgård, H. K. (2006). Discourses of rurality in a norwegian context. Norsk Geografisk Tidsskrift - Norwegian Journal of Geography. Volume 60, Issue 3, 2006, Pages $174-178$.

Jacobsen, D. I. (2005). Hvordan gjennomføre undersøkelser? Innføring $i$ samfunnsvitenskapelig metode. Kristiansand: Høyskoleforlaget. 
Kalleberg, R. (1992). Konstruktiv samfunnsvitenskap. En fagteoretisk plassering av «aksjonsforskning». Rapport nr. 24 1992. Oslo: Institutt for Sosiologi, Universitetet i Oslo.

Leknes, S., M. Tønnessen \& A. Syse (2016). Befolkningsframskrivingene 2016. Dokumentasjon av modellene BEFINN og BEFREG. Notater 2016/14, Statistisk sentralbyrå.

Lundholm, E., Garvill, J., Malmberg, G. \& Westin, K. (2004). Forced or free movers? The motives, voluntariness and selectivity of interregional migration in the Nordic countries. Population, Place and Space 10: 59-72.

Massey, D. (2005). For Space. London: Sage.

Munkejord, M. C. (2009). Hjemme i nord. En analyse av stedsopplevelser med utgangspunkt $i$ kvinnelige og mannlige innflytteres fortellinger om hverdagsliv i Havøysund og Vadsø, Finnmark. Avhandling for graden philosophiae doctor i kultur- og samfunnsfag Institutt for planlegging og lokalsamfunnsforskning, Universitetet $\mathrm{i}$ Tromsø.

Niedomysl, T. (2004). "Evaluating the effects of place-marketing campaigns on interregional migration in Sweden" Environment and Planning A 36(11) 1991 - 2009.

Orderud, G, \& Onsager, K. (1998): Flytting: mønstre og årsaker: en kunnskapsoversikt. NIBR prosjektrapport 1998:6. Norsk Institutt for by- og regionforskning, Oslo.

Perkins, H. C. \& Thorns, D.C. (2012). Place, Identity and Everyday Life in a Globalizing World. Basingstoke; Palgrave MacMillan.

Rees, P. \& Kupizsewki, M. (1999). Internal Migration and Regional Population Dynamics in Europe: A Synthesis. Council of Europe Publishing: Strasbourg.

Ringholm, T., Mikkelsen, E., Alnes P., K.Hauge, A., Lie, I., Nilsen, H. R. \& Grøtvold-Solbu, K. (2015). Økonomisk samspill og vekstmuligheter i Sør-Tromsregionen. Rapport $4 / 2015$. Norut.

Stenbacka, S. (2012). «The Rural» Intervening in the Lives of Internal and International Migrants: Migrants, Biographies and Translocal Practices. I Hedberg, C.\& do Carmo, R. M. (Red.), Translocal Ruralism: Mobility and Connectivity in European Rural Spaces. (s. 55-72). Heidelberg: Springer.

Storvoll, R., Alvig Espenes, M. \& Myrvoll, K.S. (2015). Byregion Finnsnes - samspill mellom by og bygd. By og land - hand $i$ hand. Samfunnsanalyse for Midt-Troms. Rapport.

Sørlie, K. (2006). Bosettingspreferanser, flyttemotiver og flytteprosesser. Status og perspektiver omkring den regionale befolkningsutviklingen i Norge. Notat til Kommunal og regionaldepartementet. 
Teigen H. \& Lønning, D. J., (2009). Kunnskapsstatus om tilflytting til småstader og distrikt. Kva tiltak verkar? Ein kunnskapsstudie av utviklingsrelevante norske bidrag frå perioden 1999-2009. http://www.distriktssenteret.no/filearchive/tilflytting-endelegversjon-2-.pdf

Tiller, T. (2006). Aksjonslæring - forskende partnerskap i skolen. Motoren i det nye læringsløftet. 2. utgave. Gimlemoen: Høyskoleforlaget.

United Nations (2006). World urbanization prospects: the 2005 revision, United Nations Publications.

Viken, A. (2012). Fokus på sted - fokusgruppesamtaler som metode i steds- og destinasjonsanalyser. I A. Førde, B. Kramvig, N. Gunnerud Berg \& B. Dale (red.). A finne sted. Metodologiske perspektiver $i$ stedsanalyser (205-219). Trondheim: Akademika forlag.

Winsvold, A. \& Falck, S. (2011). Modeller for å sikre medbestemmelse og medinnflytelse blant utsatte ungdomsgrupper. Oslo: Norsk institutt for forskning om oppvekst, velferd og aldring. 